\title{
Apakah Profitabilitas Memediasi Pengaruh Manajemen Modal Kerja Terhadap Nilai Perusahaan?
}

\author{
Evan Yulandreano, Apriani Dorkas Rambu Atahau, dan Imanuel Madea Sakti
}

Departemen Manajemen Fakultas Ekonomika dan Bisnis Universitas Kriten Satya Wacana (UKSW) J1. Diponegoro No. 52-60, Salatiga, 50711, Indonesia

Info Artikel Abstract

This study aims to examine the effect of working capital management on firm value with profitability as a mediating variable. This study uses a sample of 18 retail companies listed on the Indonesia Stock Exchange from 2014 to 2018. Working capital management is measured by Cash Conversion Cycle (CCC), profitability is measured by Return on Assets (ROA), and company value is measured by Tobins $Q$. Panel data regression is conducted to test the direct effect, followed by the Sobel test to test for the indirect effect. The results

Keywords:

Cash Conversion Cycle; Firm Value; Profitability; Retail Industry; Working Capital Management.

Kata Kunci:

Manajemen Modal Kerja; Nilai Perusahaan;

Profitabilitas; dan Siklus Kas

ISSN (print): 2598-7763

ISSN (online): 2598-7771 showed that working capital management increased firm value directly and indirectly through profitability. Working capital management with a shorter cycle results in greater profitability, thus driving firm value. The implication of this research is that retail companies are expected to shorten the company's cash cycle so that it has a positive impact on the company's profitability and value.

Citation: Yulandreano, E., Atahau, A.D..R., dan Sakti, I.M. (2020). Apakah Profitabilitas Memediasi Pengaruh Manajemen Modal Kerja terhadap Nilai Perusahaan? AFRE Accounting and Financial Review, 3(2): 103-114

\section{Abstraks}

Penelitian ini bertujuan untuk menguji pengaruh manajemen modal kerja terhadap nilai perusahaan dengan profitabilitas sebagai variabel mediasi. Penelitian ini menggunakan sampel 18 perusahaan ritel yang terdaftar pada Bursa Efek Indonesia tahun 2014 sampai 2018. Manajemen modal kerja diukur menggunakan Cash Conversion Cycle (CCC), profitabilitas diukur dengan Returnn on Assets (ROA), dan nilai perusahaan diukur dengan Tobins $Q$. Regresi data panel dilakukan untuk menguji pengaruh langsung, diikuti oleh uji Sobel untuk menguji pengaruh tidak langsung. Hasil penelitian menunjukkan bahwa manajemen modal kerja meningkatkan nilai perusahaan secara langsung maupun secara tidak langsung melalui profitabilitas. Manajemen modal kerja dengan siklus yang lebih pendek menghasilkan profitabilitas besar sehingga mendorong nilai perusahaan. Implikasi penelitian ini diharapkan perusahaan ritel memperpendek siklus kas perusahaan sehingga berdampak positif bagi profitabilitas dan nilai perusahaan.

JEL Classification: G31, G32

DOI: DOI: https://doi.org/10.26905/afr.v3i2.5452

\section{PENDAHULUAN}

Bisnis ritel merupakan kegiatan penjualan ba-rang dan jasa kepada konsumen sebagai pengguna akhir secara langsung. Pertumbuhan bisnis ritel didorong oleh terbukanya peluang pasar, perkembangan industri manufaktur, dan upaya-upa- ya pemerintah mengembangkan sektor ini. Pertumbuhan bisnis ritel di Indonesia mengalami peningkatan pada tahun 2018 sebesar 3,717 persen, setelah sebelumnya mengalami pelambatan mulai dari tahun 2015 sampai 2017 (Setiaji, 2019).

Semua perusahaan, termasuk perusahaan ritel, umumnya memiliki tujuan jangka pendek untuk memperoleh laba maksimal dan tujuan jangka panjang untuk meningkatkan nilai perusahaan ba- 
gi kemakmuran pemegang saham. Nilai perusahaan dapat direpresentasikan oleh harga saham bahwa semakin tinggi harga saham perusahaan maka nilai perusahaan juga semakin tinggi (Sudana, 2011; Taftazani et al., 2015; Haryanto et al., 2018; Fristiani et al., 2020; dan Banamtuan i., 2020). Nilai perusahaan dapat menambah kepercayaan bagi para pemangku kepentingan. Jika nilai perusahaan tinggi, hal ini mencerminkan kinerja perusahaan dalam keadaan baik. Salah satu upaya untuk memperoleh kinerja dan nilai perusahaan yang baik adalah manajemen modal kerja.

Modal kerja merupakan salah satu aspek penting dalam keseluruhan manajemen keuangan. Pengelolaan manajemen modal kerja merupakan tanggung jawab setiap pimpinan perusahaan. Tujuan dari modal kerja adalah menjamin likuiditas sebuah perusahaan. Perusahaan dapat menjalankan kegiatannya dan memenuhi kewajiban jangka pendek yang akan jatuh tempo dan pengeluaran operasional yang akan datang, tanpa mengorbankan profitabilitas (Panigrahi, 2017). Dalam pengelolaan manajemen modal kerja, terdapat perbedaan antara perusahaan industri jasa (sub sektor barang eceran/ritel) dengan perusahaan manufaktur. Perusahaan industri jasa melakukan pembelian persediaan secara kredit maupun tunai untuk dijual kembali tanpa melakukan proses produksi. Sebaliknya, perusahaan manufaktur melakukan pembelian persediaan selanjutnya mela- kukan proses produksi dan hasil produksi dijual secara kredit maupun tunai.

Tabel 1 menunjukkan rerata proporsi komponen modal kerja perusahaan ritel di Indonesia tahun 2014-2018. Hasil rerata komponen modal kerja terhadap total aset adalah total aset lancar (TAL/TA) sebesar 62,22\%, kas (KAS/TA) sebesar $11,91 \%$, piutang (PU/TA) sebesar 10,14\%, inventori (INV/TA) sebesar 27,68\%, total hutang lancar (THL/TA) sebesar $62,68 \%$ dan hutang usaha (HU/TA) sebesar 45,02\%. Hal ini menunjukkan bahwa nilai TAL/TA lebih rendah $0,48 \%$ dari THL/TA serta jumlah kas, piutang, dan inventori yang hanya sebesar $49,73 \%$ atau $12,95 \%$ lebih rendah dari total hutang lancar. Tingginya rerata proporsi hutang jangka pendek dan rendahnya aktiva lancar akan mempengaruhi keberlangsungan perusahaan ritel yaitu pada profitabilitas dan nilai perusahaan.

Siklus kas dengan istilah lain CCC (Cash Conversion Cycle) adalah panjangnya waktu sejak terjadi pengeluaran kas yang berhubungan dengan pembelian barang atau jasa dan penerimaan kas yang berhubungan dengan penjualan persediaan dan hasil penagihan nilai piutang (Brigham \& Houston, 2001). Siklus kas perusahaan ritel merupakan siklus pendek, hal ini dikarenakan operasional perusahaan ritel umumnya melakukan pembelian barang persediaan secara kredit.

\begin{tabular}{lrrrrrr}
\multicolumn{6}{c}{ Tabel 1. Rerata Proporsi Komponen Modal Kerja Perusahaan Ritel di Indonesia (\%) } \\
\hline Tahun & TAL/TA & KAS/TA & PU/TA & INV/TA & THL/TA & HU/TA \\
2014 & 65,67 & 10,48 & 10,46 & 27,21 & 43,62 & 23,64 \\
2015 & 60,14 & 11,98 & 10,41 & 26,25 & 62,08 & 32,67 \\
2016 & 60,87 & 11,92 & 9,52 & 27,88 & 58,08 & 46,79 \\
2017 & 60,76 & 11,87 & 10,11 & 28,19 & 72,73 & 50,01 \\
2018 & 63,66 & 13,28 & 10,21 & 28,35 & 76,87 & 72,00 \\
Rerata & 62,22 & 11,91 & 10,14 & 27,68 & 62,68 & 45,02 \\
Min & 60,14 & 10,48 & 9,52 & 26,25 & 43,62 & 23,64 \\
Max & 65,67 & 13,28 & 10,46 & 28,35 & 76,87 & 72,00 \\
\hline
\end{tabular}

Keterangan: Total Aktiva Lancar (TAL); Kas (KAS); Piutang Usaha (PU); Inventori (INV); Total Hutang Lancar (THL); Hutang Usaha (HU); Total Aset (TA).

Sumber: Bursa Efek Indonesia (BEI), data diolah.

Beberapa penelitian terdahulu menghubungkan antara manajemen modal kerja dan profitabilitas. Abuzayed (2012) menemukan bahwa manajemen modal kerja, yang diukur dengan CCC, dapat meningkatkan profitabilitas perusahaan yang diukur dengan GOP (Gross Operating Profit). Sejalan dengan temuan tersebut, Quayyum (2012) menemukan bahwa semakin rendah CCC maka semakin tinggi Return on Assets (ROA), ukuran dari profitabilitas. Manajemen modal kerja akan berdam- pak pada profitabilitas perusahaan (AmponsahKwatiah \& Asiamah, 2020; Nguyen et al., 2020; Sharma \& Kumar, 2011; Martínez-Solano \& GarcíaTeruel, 2007; dan (Deloof, 2003).

Hal ini mengindikasikan bahwa perusahaan harus memperhatikan manajemen piutang dan hutang untuk memperoleh profitabilitas tinggi. Selain itu, Mathuva (2009); Phuong \& Jyh-Tay (2010); Raheman \& Nasr (2007) menyatakan bahwa CCC yang rendah dan peran manajer terbukti mengha- 
silkan return positif bagi perusahaan.

Akoto (2013) menemukan bahwa CCC tidak berpengaruh terhadap profitabilitas yang diukur dengan Return on Equity (ROE), namun ketika menggunakan Acount Receivable Days (ARD) sebagai ukuran manajemen modal kerja, hasil menunjukkan bahwa ARD yang rendah dapat meningkatkan profitabilitas perusahaan. Hal ini sesuai dengan Deloof (2003) bahwa ARD berpengaruh negatif signifikan terhadap Gross Operating Income (GOI) yang berarti manajemen modal kerja terbukti meningkatkan profitabilitas. Namun ketika menggunakan CCC, hasil menunjukkan bahwa CCC berpengaruh negatif terhadap GOI namun tidak signifikan sehingga manajemen modal kerja tidak terbukti meningkatkan profitabilitas.

Selanjutnya, beberapa penelitian menunjukkan bahwa terdapat hubungan antara profitabilitas dan nilai perusahaan. Gamayuni (2015) yang menemukan bahwa profitabilitas yang diukur dengan ROA berpengaruh positif terhadap nilai perusahaan yang diukur menggunakan dengan Tobin's $Q$ pada perusahaan manufaktur yang terdaftar di BEI. Hal ini sesuai dengan Dewi \& Wirajaya (2013); Kartika \& Abundanti (2019) bahwa semakin tinggi profitabilitas, semakin tinggi nilai perusahaan.

Manajemen modal kerja selain berpengartuh terhadap profitabilitas juga berpengaruh terhadap nilai perusahaan. Setyanto \& Permatasari (2014) menemukan bahwa manajemen modal kerja yang diukur dengan CCC dapat meningkatkan nilai perusahaan yang diukur menggunakan Tobin's $Q$ pada perusahaan peserta CGPI (Corporate Governance Perception Index) yang tercatat di BEI pada tahun 2003-2011. Temuan ini mendukung temuan Ogundipe et al. (2012) bahwa manajemen modal kerja dapat meningkatkan nilai perusahaan serta profitabilitas perusahaan di Nigeria.

Penelitian Nastiti et. al. (2019) menunjukkan bahwa profitabilitas dapat memediasi hubungan antara manajemen modal kerja dan sustainable growth pada perusahaan manufaktur yang terdaftar di BEI periode 2010-2017. Namun, Pratama \& Wiksuana, (2016) menunjukkan hasil sebaliknya bahwa profitabilitas tidak dapat memediasi hubungan antara ukuran perusahaan dan nilai perusahaan pada perusahaan telekomunikasi yang terdaftar pada BEI periode 2009-2013. Hal ini menunjukkan bahwa peran profitabilitas sebagai pemediasi masih menunjukkan inkonsistensi hasil. Oleh karena itu, penelitian ini akan menguji peran profitabilitas sebagai variabel mediasi antara manajemen modal kerja dan nilai perusahaan.

Penelitian ini berfokus pada perusahaan ri- tel yang tercatat dari BEI pada tahun 2014-2018 karena, perusahaan ritel mempunyai siklus yang pendek tanpa melakukan proses produksi. Adapun tujuan penelitian untuk menganalisis peran profitabilitas sebagai variabel mediasi pada hubungan manajemen modal kerja terhadap nilai perusahaan pada perusahaan ritel.

\section{PENGEMBANGAN HIPOTESIS}

Nilai perusahaan dapat dicerminkan dari harga saham, semakin tinggi harga saham maka akan meningkatkan return investor dan meningkatkan nilai perusahaan. Pengelolaan yang dilakukan oleh manajer dengan baik dapat berpengaruh terhadap nilai perusahaan. Pengoptimalkan nilai perusahaan dengan keputusan manajer dapat mempengaruhi pemegang saham (Dewi, 2008). Besarnya jumlah keuntungan terhadap kesejahteraan pemegang saham berupa dividen. Nilai perusahaan umumnya diukur menggunakan nilai Tobin's Q (Ardiana, 2012). Nilai Tobin's Q dalam perhi-tungan melibatkan nilai kapitalisasi pasar (Market Value of all outstanding Stock/MVS) dan hutang perusahaan dibagi dengan total aset perusahaan.

Peran penting manajemen modal kerja terkait dengan kenyataan bahwa sebagian besar perusahaan menginvestasikan sejumlah besar uang ke dalam aset lancar dan mengandalkan kewajiban lancar sebagai sumber pembiayaan (Deloof 2003, Koralun-Bereźnicka 2014). Manajemen modal kerja terdiri dari semua keputusan yang terkait dengan pengelolaan aset dan kewajiban lancar, yaitu menentukan jumlah optimal kas, piutang, persediaan, dan kewajiban lancar dan hubungan antara kewajiban lancar dan aset lancar (Abuzayed, 2012). Manajemen modal kerja juga mengacu pada kegiatan pendanaan, investasi dan kontrol aset lancar bersih melalui berbagai kebijakan perusahaan (Padachi et. al. 2012). Dengan mengelola modal kerja, perusahaan dapat mempersingkat siklus operasi dan kas sehingga pada akhirnya meningkatkan profitabilitas perusahaan (Raheman et. al. 2010, Tran et. al. 2017).

Manajemen modal kerja umumnya diukur menggunakan rasio CCC (Cash Conversion Cycle) (Syarief \& Wilujeng, 2009). Rasio CCC dalam perhitungan melibatkan DIO (Days Inventory Outstanding) ditambah DSO (Days Sales Outstanding) dikurangi dengan DPO (Days Payable Outstanding). CCC yang pendek dapat menunjukkan kinerja baik perusahaan, sebaliknya CCC yang panjang menunjukkan kinerja yang tidak baik. Modal kerja dengan siklus yang pendek dapat mendorong perusahaan 
untuk menghasilkan profitabilitas yang besar.

Kinerja perusahaan dinilai dari kemampuan perusahaan untuk menghasilkan laba. Indikator kinerja perusahaan yang ditunjukkan melalui laba perusahaan merupakan profitabilitas. Profitabilitas merupakan aspek penting dikarenakan profitabilitas mengukur kinerja keuangan pada suatu perusahaan untuk menjadi referensi dalam menilai perusahaan (Sutrisno, 2020; Pervan et al., 2019; Ayu \& Suarjaya, 2017; Seelanatha, 2011; dan Goddard et al., 2005).

Profitabilitas yang meningkat dapat diartikan bahwa kinerja perusahaan baik sehingga peluang di masa mendatang juga semakin baik. Rasio profitabilitas terdiri Return on Equity (ROE), Return on Asset (ROA), Gross Profit Margin dan Operating Profit Margin. ROA merupakan salah satu alat ukur yang bersifat menyeluruh (Munawir, 2004). ROA menunjukkan bagaimana kualitas manajemen dalam mengelola aset perusahaan, semaskin tinggi ROA menunjukkan manajemen semakin baik dalam mengelola asset perusahaan (Wibowo \& Yuliana, 2020 dan (Haryanto et al., 2020); (Agustina et al., 2018); (Bateni et al., 2014). Rasio ROA dalam perhitungan melibatkan laba setelah pajak dibagi dengan total aktiva.

\section{Manajemen Modal Kerja terhadap Profitabilitas}

Manajemen modal kerja yang baik yaitu siklus konversi kas pendek untuk mempercepat penjualan persediaan, mempercepat periode penagihan piutang, dan memperlambat pembayaran hutang perusahaan sehingga profitabilitas perusahaan tinggi. Semakin pendek siklus kas di perusahaan ritel, semakin tinggi profitabilitas. siklus kas menunjukkan adanya efisiensi penggunaan kas sehingga menurunkan biaya modal dan akhirnya dapat meningkatkan return perusahaan.

Penelitian Akoto (2013); Deloof (2003) menunjukkan bahwa manajemen modal kerja yang diukur dengan CCC tidak terbukti meningkatkan profitabilitas. Sedangkan, penelitian Quayyum (2011), Dong \& Su (2010), Mathuva (2009), Raheman \& Nasr (2007) menunjukkan bahwa manajemen modal (CCC) dapat meningkatkan profitabilitas. Hipotesis penelitian dirumuskan sebagai berikut:

$\mathrm{H}_{1}$ : Manajemen modal kerja meningkatkan profitabilitas.

\section{Profitabilitas terhadap Nilai Perusahaan}

Profitabilitas perusahaan yang tinggi merupakan sinyal bahwa perusahaan memiliki prospek positif sehingga nilai perusahaan juga tinggi bagi investor. Hubungan antara profitabilitas dan nilai perusahaan sejalan dengan signaling theory yaitu peningkatan profitabilitas yang terdapat di laporan keuangan dapat memberikan sinyal positif bagi investor berkaitan dengan kinerja perusahaan (Rizqia et. al., 2013). Penelitian Dewi \& Wirajaya (2013), Gamayuni (2015), Putu et. al. (2014) menunjukkan bahwa profitabilitas berpengaruh positif terhadap nilai perusahaan. Hipotesis penelitian dirumuskan sebagai berikut:

$\mathrm{H}_{2}$ : Profitabilitas meningkatkan nilai perusahaan.

\section{Manajemen Modal Kerja terhadap Nilai Perusa-} haan

Salah satu upaya perusahaan untuk meningkatkan nilai perusahaan adalah melalui manajemen modal kerja. Penelitian Ogundipe et. al. (2012) menunjukkan bahwa manajemen modal kerja meningkatkan nilai perusahaan. Hal ini menunjukkan bahwa semakin pendek siklus konversi kas mengindikasikan kinerja perusahaan semakin baik. Hal ini sesuai dengan Setyanto \& Permatasari (2014) bahwa manajemen modal kerja yang diukur de-ngan CCC meningkatkan nilai perusahaan. Hipotesis penelitian dirumuskan sebagai berikut:

$\mathrm{H}_{3}$ : Manajemen modal kerja meningkatkan nilai perusahaan.

\section{Manajemen Modal Kerja terhadap Nilai Perusa- haan dengan Profitabilitas sebagai Variabel Mediasi}

Temuan penelitian Nastiti et. al. (2019) menunjukkan bahwa profitabilitas dapat memediasi hubungan antara manajemen modal kerja dan sustainable growth. Dengan demikian, perusahaan dapat meningkatkan sustainable growth dengan meningkatkan kemampuan perusahaan untuk menghasilkan laba. Peningkatan profitabilitas memudahkan perusahaan untuk menghasilkan dana internal yang penting untuk meningkatkan sustainable growth. Hipotesis penelitian dirumuskan sebagai berikut:

$\mathrm{H}_{4}$ : Manajemen modal kerja berpengaruh positif terhadap nilai perusahaan dengan profitabilitas sebagai variabel mediasi.

\section{DATA DAN METODE}

Sampel penelitian adalah perusahaan ritel yang terdaftar pada Bursa Efek Indonesia (BEI) tahun 2014 sampai 2018 yang dipilih menggunakan metode purposive sampling. Kriteria pemilihan sampel ditunjukkan oleh Tabel 2 sedangkan daftar 18 perusahaan terpilih ditunjukkan oleh Tabel 3. Data panel perusahaan diperoleh dari laporan keuangan 
dan laporan tahunan perusahan terkait. Variabel dependen adalah nilai perusahaan, variabel independen adalah manajemen modal, variabel mediasi adalah profitabilitas serta beberapa variabel kontrol. Daftar variabel dan pengukuran ditunjukkan oleh Tabel 4.

Tabel 2. Pemilihan Sampel Berdasarkan Kriteria

\begin{tabular}{clcc}
\hline No & \multicolumn{1}{c}{ Kriteria } & $\begin{array}{c}\text { Jumlah } \\
\text { Perusahaan }\end{array}$ \\
\hline 1 & $\begin{array}{l}\text { Perusahaan ritel yang } \\
\text { konsisten tercatat di BEI }\end{array}$ & 24 \\
tahun 2014-2018. & \\
2 & $\begin{array}{l}\text { Perusahaan ritel yang tidak } \\
\text { memiliki kelengkapan data }\end{array}$ & $(6)$ \\
& selama tahun 2014-2018. & \\
\hline Jumlah Sampel Akhir & 18 \\
Tahun Pengamatan & 5 \\
Jumlah Pengamatan & 90 \\
\hline
\end{tabular}

Tabel 3. Daftar Sampel Penelitian

\begin{tabular}{|c|c|c|}
\hline No & Kode & Nama Perusahaan \\
\hline 1 & ACES & Ace Hardware Indonesia Tbk \\
\hline 2 & AMRT & Sumber Alfaria Trijaya Tbk. \\
\hline 3 & CENT & Telekomunikasi \\
\hline 4 & CSAP & Catur Sentosa Adiprana Tbk. \\
\hline 5 & ERAA & Erajaya Swasembada Tbk. \\
\hline 6 & MIDI & Midi Utama Indonesia Tbk. \\
\hline 7 & HERO & Hero Supermarket Tbk. \\
\hline 8 & LPPF & Matahari Department Store Tbk. \\
\hline 9 & KOIN & Kokoh Inti Arebama Tbk. \\
\hline 10 & MAPI & Mitra Adiperkasa Tbk. \\
\hline 11 & MPPA & Matahari Putra Prima Tbk. \\
\hline 12 & RALS & Ramayana Lestari Sentosa Tbk. \\
\hline 13 & RANC & Supra Boga Lestari Tbk. \\
\hline 14 & ECII & Electronic City Indonesia Tbk. \\
\hline 15 & SONA & Sona Topas Tourism Industry Tbk \\
\hline 16 & TELE & Triphone Mobile Indonesia Tbk. \\
\hline 17 & GLOB & Global Teleshop Tbk. \\
\hline 18 & TRIO & Trikomsel Oke Tbk. \\
\hline
\end{tabular}

Penelitian ini menggunakan teknik analisis regresi data panel untuk pengujian langsung dan Sobel test untuk pengujian tidak langsung (hipotesis mediasi) dengan program STATA 14. Bentuk persamaan model matematis dalam penelitian ini adalah:

$$
\begin{aligned}
& \mathrm{Z}_{\mathrm{it}}=\alpha+\beta_{1} \mathrm{X}_{\mathrm{it}}+\beta_{3} \sum \text { kontrol }_{\mathrm{it}}+\varepsilon_{\mathrm{it}} \\
& \mathrm{Y}_{\mathrm{it}}=\alpha+\beta_{1} \mathrm{Z}_{\mathrm{it}}+\beta_{3} \sum \text { kontrol }_{\mathrm{it}}+\varepsilon_{\mathrm{it}} \\
& \mathrm{Y}_{\mathrm{it}}=\alpha+\beta_{1} \mathrm{X}_{\mathrm{it}}+\beta_{3} \sum \text { kontrol }_{\mathrm{it}}+\varepsilon_{\mathrm{it}} \\
& \mathrm{Y}_{\mathrm{it}}=\alpha+\beta_{1} \mathrm{X}_{\mathrm{it}}+\beta_{2} \mathrm{Z}_{\mathrm{it}}+\beta_{3} \sum \text { kontrol }_{\mathrm{it}}+\varepsilon_{\mathrm{it}}
\end{aligned}
$$

Dimana $Y$ adalah Nilai perusahaan, $X$ adalah variabel independen (CCC), dan $Z$ merupakan variabel mediasi (ROA). Variabel kontrol terdiri dari 3 variabel mulai dari DER, TATO, dan AGE. Selanjutnya a adalah konstanta, $\beta$ koefisien regresi variabel bebas, lalu i menunjukkan data cross section laporan keuangan perusahaan ritel, $\mathrm{t}$ sebagai time series tahun 2014-2018, dan $\varepsilon_{i t}$ adalah eror di waktu $t$.

\section{HASIL}

Statistik deskriptif (Tabel 5) menunjukkan bahwa nilai rata-rata nilai perusahaan (Tobin's Q) sebesar 2,668. Nilai Tobin's $Q$ tinggi atau lebih dari 1 , maka perusahaan berpotensi menghasilkan tingkat return lebih besar dibandingkan dengan biaya aktiva yang dikeluarkan dan mengindikasikan prospek perusahaan baik.

Modal kerja yang diukur dengan CCC memiliki rata-rata -141 hari. Siklus kas yang negatif menunjukkan bahwa durasi hutang yang diterima dari pemasok barang dagangan lebih lama dibandingkan durasi siklus operasi sehingga siklus kas industri ritel sangat efisien.

Tabel 4. Variabel dan Pengukuran

\begin{tabular}{llc}
\hline \multicolumn{1}{c}{ Variabel } & Proksi & Indikator \\
\hline $\begin{array}{l}\text { Dependen } \\
\text { Nilai Perusahaan }\end{array}$ & Tobins'sQ & $\frac{(M V S+D E B T)}{\text { TOTA }}$ \\
$\begin{array}{l}\text { Independen } \\
\text { Manajemen Modal Kerja } \\
\begin{array}{l}\text { Profitabilitas } \\
\text { Kontrol }\end{array}\end{array}$ & CCC \\
Leverage & ROA & Laba Setelah Pajak $($ EBIT $)$ \\
Total Aset Turnover & DER & Total Aktiva \\
Umur Perusahan & TATO & $\frac{\text { Total Hutang }}{\text { Ekwitas }}$ \\
\hline
\end{tabular}


Profitabilitas yang diukur dengan ROA memiliki rata-rata $-22,4$ persen, menunjukkan kemampuan perusahaan ritel dari modal yang diinvestasikan secara keseluruhan belum mampu untuk menghasilkan laba. Semakin tinggi ROA menunjukkan kinerja perusahaan yang semakin baik.
Rasio leverage diproksikan dengan DER. Rata-rata DER sebesar 155,1\%, hal ini menunjukkan utang lebih tinggi dari nilai ekuitas. Semakin tinggi DER menunjukkan risiko perusahaan akan semakin tinggi.

Tabel 5. Statistik Deskriptif

\begin{tabular}{llrrrr}
\hline \multicolumn{1}{c}{ Variabel } & Obs & \multicolumn{1}{c}{ Rerata } & Std. Dev. & \multicolumn{1}{c}{ Min } & \multicolumn{1}{c}{ Maks. } \\
\hline Tobin's Q & 90 & 2,668 & 5,012 & 0,002 & 31,693 \\
CCC & 90 & $-141,375$ & 317,638 & $-1.586,660$ & 120,869 \\
ROA & 90 & $-0,224$ & 1,511 & $-10,889$ & 0,458 \\
DER & 90 & 1,551 & 2,558 & $-1,220$ & 20,430 \\
TATO & 90 & 2,606 & 2,826 & 0,067 & 20,425 \\
AGE & 90 & 3,040 & 0,565 & 1,792 & 4,094 \\
\hline
\end{tabular}

TATO memiliki rata-rata $260,06 \%$. Semakin tinggi nilai TATO menunjukkan semakin tinggi nilai penjualan bersih yang diperoleh, dengan nilai penjualan yang tinggi memberikan harapan memperoleh laba yang tinggi.

Pemilihan model estimasi pada Tabel 6 menunjukkan bahwa model persamaan 1 menggunakan metode regresi Fixed Effect Model (FEM) sebagai model estimasi terbaik. Pada model per-samaan 2, model persamaan 3 dan model persamaan 4 menggunakan metode regresi Random Effect Model (REM) sebagai model estimasi terbaik.

Pengujian asumsi klasik dilakukan setelah menentukan metode estimasi guna melihat permasalahan hasil regresi maupun data pada masingmasing model penelitian. Pengujian asumsi klasik ini digunakan pada model FEM dan PLS (Pooled Least Square). Model REM tidak memerlukan pengujian asumsi klasik karena uji sudah mengakomodasi masalah hetekedastisitas dan autokorelasi. Hasil pengujian pada Tabel 7 menun-

Tabel 7. Hasil Uji Asumsi Klasik

\begin{tabular}{llll}
\hline \multicolumn{1}{c}{ Metode } & Prob. & \multicolumn{1}{c}{ Keputusan } \\
\hline Model 1 & Modified Wald Test & 0,000 & Ada Heteroskedastisitas \\
Heteroskedastisitas & Wooldridge test & 0,000 & Ada Autokorelasi \\
Autokorelasi & & & \\
\hline
\end{tabular}

Tabel 8 menunjukkan hasil uji korelasi antar variabel yang berkisar di antara $-0,550<p<-0,170$. Korelasi antara CCC terhadap TOBINSQ menunjukkan hubungan negatif dengan nilai korelasi yaitu $-0,550$. Hasil uji ini mengindikasikan tidak terdapat masalah multikolinearitas karena tidak ada koefisien korelasi lebih tinggi dari 0,7 dan nilai VIF tidak terdapat lebih besar dari 10. Pengujian hipotesis berdasarkan 18 sampel data perusahaan ritel ditunjukkan pada Tabel 9 .

Berdasarkan Tabel 9 model 1, hasil menun- jukkan bahwa terdapat masalah heteroskedastisitas dan autokorelasi pada model 1 sehingga nantinya akan ditambahkan robust standard error pada saat pengujian hipotesis.

Tabel 6. Pemilihan Model Estimasi

\begin{tabular}{lcc}
\hline & Prob. & Keputusan \\
\hline Model 1 (ROA) & & \\
Uji Chow & 0,011 & FEM \\
Uji Lagrange Multiplier & 1,000 & PLS \\
Uji Hausman & 0,000 & FEM \\
Model 2 (Tobin's Q) & & \\
Uji Chow & 0,000 & FEM \\
Uji Lagrange Multiplier & 0,000 & REM \\
Uji Hausman & 0,856 & REM \\
Model 3 (Tobin's Q) & & \\
Uji Chow & 0,000 & FEM \\
Uji Lagrange Multiplier & 0,000 & REM \\
Uji Hausman & 0,638 & REM \\
Model 4 (Tobin's Q) & & \\
Uji Chow & 0,000 & FEM \\
Uji Lagrange Multiplier & 0,000 & REM \\
Uji Hausman & 0,999 & REM \\
\hline
\end{tabular}

jukkan bahwa CCC berpengaruh negatif signifikan terhadap ROA, atau berarti manajemen modal kerja meningkatkan profitabilitas. Hal ini berarti semakin pendek siklus kas perusahaan ritel maka semakin tinggi profitabilitas perusahaan. Hal ini membuktikan terdapat efisiensi penggunaan kas sehingga menurunkan biaya modal dan meningkatkan return perusahaan. Hasil lain menunjukkan bahwa variabel kontrol TATO berpengaruh negatif signifikan pada ROA, sedangkan DER dan AGE tidak terbukti berpengaruh terhadap ROA. 
Tabel 8. Matriks Korelasi

\begin{tabular}{|c|c|c|c|c|c|c|c|}
\hline & Tobin'sQ & CCC & ROA & DER & TATO & AGE & VIF \\
\hline TOBINSQ & 1,0000 & & & & & & \\
\hline CCC & $-0,5504$ & 1,0000 & & & & & 1,27 \\
\hline $\mathrm{ROA}$ & $-0,1697$ & $-0,1030$ & 1,0000 & & & & 1,75 \\
\hline DER & $-0,0585$ & 0,1312 & 0,2099 & 1,0000 & & & 1,43 \\
\hline TATO & 0,4035 & $-0,1820$ & $-0,6469$ & $-0,2034$ & 1,0000 & & 2,84 \\
\hline AGE & 0,1069 & $-0,0846$ & 0,1719 & 0,0102 & $-0,3495$ & 1,0000 & 2,46 \\
\hline Mean VIF & & & & & & & 1,95 \\
\hline
\end{tabular}

Selanjutnya, pada model 2, hasil menunjukkan bahwa ROA berpengaruh positif signifikan pada Tobin's $Q$, atau berarti profitabilitas meningkatkan nilai perusahaan. Perusahaan ritel yang mampu menghasilkan laba tinggi akan meningkatkan nilai perusahaan bagi investor. Selain itu, variabel kontrol TATO dan AGE berpengaruh po-sitif signifikan pada Tobin's $Q$ yang membuktikan semakin cepat perputaran aset dalam menunjang penjualan dan perusahaan yang sudah lama berdiri akan meningkatkan nilai perusahaan. Sedangkan DER tidak berpengaruh terhadap Tobin's Q.

Pada model 3, hasil menunjukkan bahwa CCC berpengaruh negatif signifikan terhadap Tobin's $Q$ atau berarti manajemen modal kerja meningkatkan nilai perusahaan. Hasil lainnya pada variabel kontrol AGE berpengaruh positif signifikan pada Tobin's Q, sedangkan DER dan TATO tidak berpengaruh. Terakhir, pada model 4, CCC berpengaruh negatif signifikan terhadap Tobin's $Q$ atau berarti manajemen modal kerja terhadap profitabilitas. Dalam pengujian ini, ROA dimasukkan ke dalam model sebagai variabel mediasi dengan hasil ROA berpengaruh positif signifikan terhadap Tobin's $Q$ atau profitabilitas meningkatkan nilai perusahaan.

Hasil ini mengindikasikan bahwa manajemen modal kerja dengan siklus pendek dapat mempercepat penjualan persediaan, penagihan nilai piutang dan memperlambat pembayaran nilai hutang sehingga meningkatkan profitabilitas dan selanjutnya mendorong nilai perusahaan. Variabel kontrol TATO dan AGE ditemukan berpengaruh positif terhadap Tobin's Q, sedangkan DER tidak berpengaruh.

Hasil regresi pada kerangka penelitian dapat dilihat pada Gambar 1. pengaruh langsung (direct effect), pengaruh tidak langsung (indirect effect), dan pengaruh total (total effect) dapat dilihat pada Tabel 10. Hasil menunjukkan nilai total effect lebih kecil dari direct effect, karena adanya pengaruh langsung profitabilitas terhadap nilai perusahaan yang bernilai positif sebesar 1,194 lebih besar dari pengaruh langsung manajemen modal kerja terhadap nilai perusahaan. Hal ini mengindikasikan bahwa manajemen modal kerja dapat meningkatkan nilai perusahaan secara langsung maupun tidak langsung melalui pengaruh profitabilitas terhadap nilai perusahaan.

Untuk mengetahui peran mediasi dari profitabilitas, selanjutnya dilakukan Sobel test. Hasil ditunjukkan pada Tabel 11.

\begin{tabular}{cccc} 
Tabel 10. Direct Effect, Indirect Effect, dan Total Effect \\
\hline Jalur & Direct & Indirect & Total \\
& $\begin{array}{c}\text { Effect } \\
\text { (c) }\end{array}$ & $\begin{array}{c}\text { Effect } \\
\left(\mathrm{c}^{\prime}=\mathrm{a} \times \mathrm{b}\right)\end{array}$ & $\begin{array}{c}\text { Effect } \\
\left(\mathrm{c}+\mathrm{c}^{\prime}\right)\end{array}$ \\
\hline CCC $\rightarrow$ ROA $\rightarrow$ & $-0,009$ & 0,003 & $-0,006$ \\
Tobin's Q & & & \\
\hline
\end{tabular}

Menurut Baron dan Kenny (1986), ada tiga alternatif hasil peran mediasi. Pertama, pengaruh variabel independen pada variabel dependen menjadi tidak signifikan atau sebaliknya di hadapan variabel mediasi. Hal ini menyiratkan bahwa variabel mediasi bertindak sebagai mediator penuh dalam hubungan. Kedua, pengaruh variabel independen terhadap variabel dependen tetap signifikan di hadapan variabel mediasi, menunjukkan bahwa terdapat mediasi parsial. Ketiga, ketika kedua kondisi ini tidak ada, efek mediasi dianggap tidak signifikan.

Hasil uji Sobel, uji Arorian, dan uji Goodman pada Tabel 11 menunjukkan bahwa profitabilitas (ROA) dapat memediasi pengaruh negatif signifikan manajemen modal kerja (CCC) terhadap nilai perusahaan (Tobin's Q). Hasil ini menunjukkan bahwa perusahaan dengan manajemen modal kerja siklus pendek akan meningkatkan profitabilitas dan selanjutnya meningkatkan nilai perusahaan. Namun hasil ini menunjukkan bahwa terdapat mediasi parsial yaitu manajemen modal kerja dapat mempengaruhi nilai perusahaan dengan atau tanpa melalui profitabilitas. Hasil ini memberi implikasi bagi perusahaan ritel bahwa manajemen modal kerja sebagai upaya penting perusahaan untuk meningkatkan profitabilitas sekaligus nilai perusahaan bagi investor. 
Tabel 9. Hasil Regresi

\begin{tabular}{lcccc}
\hline Variabel & $\begin{array}{c}\text { Model 1 } \\
\text { ROA }\end{array}$ & $\begin{array}{c}\text { Model 2 } \\
\text { Tobin's }\end{array}$ & $\begin{array}{c}\text { Model 3 } \\
\text { Tobin's }\end{array}$ & $\begin{array}{c}\text { Model } 4 \\
\text { Tobin's }\end{array}$ \\
\hline CCC & $-0,0026^{* * *}$ & & $-0,0092^{* *}$ & $-0,0076^{*}$ \\
& $(0,007)$ & & $(0,030)$ & $(0,081)$ \\
ROA & & $1,1939^{* * *}$ & & $0,7930^{* *}$ \\
& & $(0,000)$ & & $(0,030)$ \\
DER & 0,0022 & 0,0557 & 0,1023 & 0,0948 \\
& $(0,941)$ & $(0,841)$ & $(0,483)$ & $(0,569)$ \\
TATO & $-0,5083^{* * *}$ & $1,1330^{* *}$ & 0,4581 & $0,8349^{*}$ \\
& $(0,000)$ & $(0,033)$ & $(0,483)$ & $(0,075)$ \\
AGE & 2,1623 & $2,3959^{* *}$ & $1,5765^{* *}$ & $1,5942^{* *}$ \\
& $(0,163)$ & $(0,031)$ & $(0,047)$ & $(0,037)$ \\
Konstanta & $-5,8458$ & $-7,3861$ & $-4,7838$ & $-5,3980$ \\
R-Square & 0,2135 & 0,2241 & 0,4156 & 0,4437 \\
Model & Fixed Effect & Random Effect & Random Effect & Random Effect \\
\hline
\end{tabular}

Catatan: Sig. $\alpha<0,1 *$, Sig. $a<0,05 * *$, Sig. $a<0,01$ ***.

Sumber: Hasil Olah STATA14

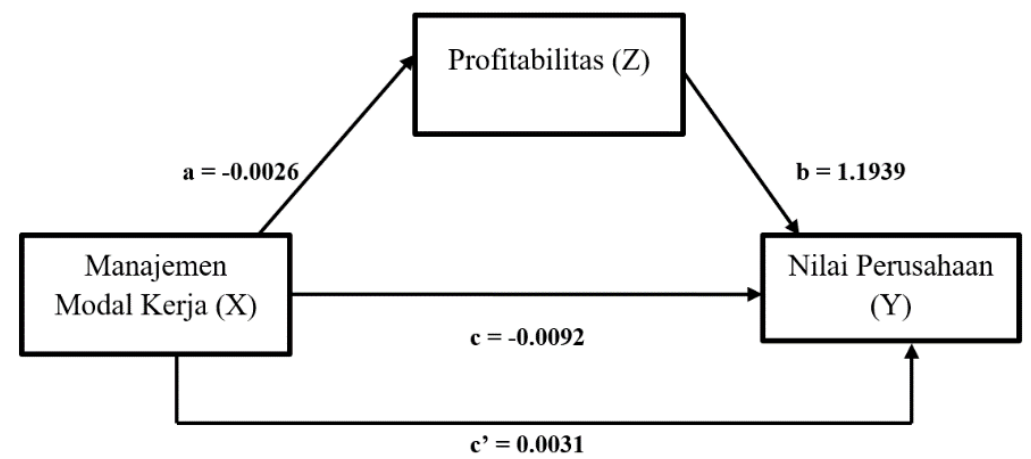

Gambar 1. Hasil Regresi Kerangka Penelitian

Tabel 11. Hasil Sobel Test

\begin{tabular}{lcc}
\hline & Koefisien & Keputusan \\
\hline Sobel & $0,0030^{* *}$ & Mediasi \\
Aroian & $0,0032^{* *}$ & Parsial \\
Goodman & $0,0028^{* *}$ & \\
\hline
\end{tabular}

Sig. $a<0,1^{*}$, Sig. $a<0,05^{* *}$, Sig. $a<0,01^{* * *}$

\section{PEMBAHASAN}

\section{Manajemen Modal Kerja terhadap Profitabilitas}

Hasil penelitian menunjukkan bahwa manajemen modal kerja berpengaruh terhadap profitabilitas. Perusahaan yang mampu mengelola modal kerjanya dengan baik, menunjukkan adanya efisiensi dan efektifitas manajemen dalam menggunakan modal kerja. Hasil penelitian mendukung temuan pene-litian Quayyum (2012), Dong \& Su (2010), Mathuva (2009), Raheman \& Nasr (2007) Hal ini menunjukkan bahwa pada perusahaan ritel dengan modal kerja siklus pendek membuat kinerja semakin baik karena dapat mempercepat penjualan persediaan, mempercepat periode penagihan piutang, dan memperlambat pembayaran utang perusahaan sehingga menghasilkan profitabilitas tinggi.

\section{Profitabilitas terhadap Nilai Perusahaan}

Hasil penelitian menunjukkan bahwa profitabilitas meningkatkan terhadap nilai perusahaan. Hasil penelitian ini mendukung temuan penelitian Dewi \& Wirajaya (2013), Gamayuni (2015), Putu et. al. (2014). Hal ini menunjukkan bahwa semakin tinggi profitabilitas perusahaan ritel, maka semakin tinggi nilai perusahaan. Peningkatan profitabilitas ini memberikan sinyal positif bagi investor bahwa kinerja perusahaan ke depan memiliki prospek positif (Rizqia et. al., 2013). 
Manajemen Modal Kerja terhadap Nilai Perusahaan

Hasil penelitian menunjukkan bahwa manajemen modal kerja meningkatkan terhadap nilai perusahaan. Penelitian ini sejalan dengan temuan penelitian Ogundipe et. al. (2012). Semakin pendek siklus konversi kas perusahaan ritel, maka semakin baik nilai perusahaan bagi investor. Perusahaan yang memiliki siklus kas pendek mempercepat penjualan barang persediaan, penagihan nilai piutang dan memperlambat pembayaran nilai hutang. Perusahaan dengan manajemen modal kerja yang baik menunjukkan perputarankas, pertputaran piutang maupun perputan persediaan yang cepat. Hal ini mengindikasikan penjualan perusahaan tinggi. Penjualan yang tinggi merupakan sintyal positif bagi investor, jika perusahaan tersebut tumbuh dengan baik. Hal ini membuat perusahaan mampu mengumpulkan kas yang diperlukan untuk kegiatan operasional sehari-hari, sehingga tidak memakai sumber dana dari luar dan tidak ada pinjaman dana (Syarief \& Wilujeng, 2009). Hal ini merupakan sinyal baik bagi investor. Hasil penelitian ini sejalan dengan temuan penelitian Dhole et al. (2019), Arachchi et al. (2017), dan Wasiuzzaman (2015).

\section{Manajemen Modal Kerja terhadap Nilai Perusa- haan dengan Profitabilitas sebagai Variabel Mediasi}

Hasil penelitian menunjukkan bahwa profitabilitas meningkatkan manajemen modal kerja berpengaruh positif terhadap nilai perusahaan dengan profitabilitas sebagai variabel mediasi. Dalam hal ini, peran mediasi yang ditemukan adalah mediasi parsial, dimana manajemen modal kerja dapat meningkatkan nilai perusahaan dengan atau tanpa melalui profitabilitas terlebih dahulu.

Hasil yang mendukung penelitian ini oleh Nastiti et. al. (2019) yang menunjukkan hasil bahwa profitabilitas dapat memediasi hubungan antara manajemen modal kerja dan sustainable growth. Dengan demikian, perusahaan ritel dengan siklus pendek dapat menghasilkan profitabilitas yang baik melalui perolehan laba perusahaan, sehingga hal ini mendorong nilai perusahaan tinggi karena merupakan sinyal positif bagi investor.

\section{SIMPULAN DAN SARAN}

Penelitian ini bertujuan untuk menguji pengaruh manajemen modal kerja terhadap nilai perusahaan dengan profitabilitas sebagai variabel mediasi. Hasil menunjukkan bahwa manajemen modal kerja meningkatkan profitabilitas, manajemen modal kerja meningkatkan nilai perusahaan, profitabilitas meningkatkan nilai perusahaan dan manajemen modal kerja berpengaruh positif terhadap nilai perusahaan dengan profitabilitas sebagai variabel mediasi.

Penelitian ini berfokus pada karakteristik modal kerja pada perusahaan ritel, dan tidak memasukkan periode krisis seperti pada periode pandemi COVID-19 yang mungkin merupakan salah satu faktor yang mempengaruhi kinerja industri ritel. Penelitian selanjutnya dapat memperpanjang periode pengamatan yang mencakup periode krisis. Selain itu, penelitian selanjutnya dapat melibatkan industri lain yang memiliki karakteristik modal kerja berbeda seperti industri manufaktur dan menggunakan ukuran kinerja perusahaan lainnnya sehingga hasil lebih komprehensif.

\section{DAFTAR PUSTAKA}

Abuzayed, B. (2012). Working capital management and firms' performance in emerging markets: The case of Jordan. International Journal of Managerial Finance, 8(2), 155-179. https://doi.org/10.1108/17439131211216620

Agustina, A., Sulia, S., \& Rice, R. (2018). Faktor faktor yang mempengaruhi profitabilitas dan dampaknya terhadap manajemen laba. Jurnal Akuntansi, 22(1), 18-32. https://doi.org/10.24912/ja.v22i1.320

Akoto, K. (2013). Working capital management and profitability: Evidence from Ghanaian listed manufacturing firms. Journal of Economics and International Finance, 5(9), 373-379. https://doi.org/10.5897/jeif2013.0539

Amponsah-Kwatiah, K., \& Asiamah, M. (2020). Working capital management and profitability of listed manufacturing firms in Ghana. International Journal of Productivity and Performance Management. https:// doi.org/10.1108/IJPPM-02-2020-0043

Arachchi, A. N. H., Perera, W., \& Vijayakumaran, R. (2017). The Impact of Working Capital Management on Firm Value: Evidence from a Frontier Market. Asian Journal of Finance $\mathcal{E}$ Accounting, 9(2), 399. https://doi.org/10.5296/ajfa.v9i2.12449

Ardiana, P. A. (2012). Variabel-variabel yang mempengaruhi Tobin's $\mathrm{Q}$ brokerage house di Indonesia. Jurnal Ilmiah Akuntansi Dan Bisnis, 7(2), 163-177.

Banamtuan, O., Zuhroh, D., \& Sihwahjoeni, S. (2020). Asset Management and Capital 
Ownership on Firm Value: Through Profitability. AFRE (Accounting and Financial Review), 3(1), 83-92. https://doi.org/10.26905/afr.v3i1.4296

Baron, R. M., \& Kenny, D. A. (1986). The moderator-mediator variable distiction in social psychological research: conceptual, strategic, and statistical considerations. Journal of Personality and Social Psychology, 51(6), 11731182. $\quad$ https://doi.org/10.1037/00223514.51.6.1173

Bateni, L., Vakilifard, H., \& Asghari, F. (2014). The Influential Factors on Capital Adequacy Ratio in Iranian Banks. International Journal of Economics and Finance, 6(11), 108-116. https://doi.org/10.5539/ijef.v6n11p108

Brigham, E. F., \& Houston, J. F. (2001). Manajemen keuangan (8th ed.). Erlangga.

Bursa Efek Indonesia. (2019). Laporan keuangan dan tahunan perusahaan tercatat.

Deloof, M. (2003). Does working capital management affect profitability of Belgian firms? Journal of Business Finance \& Accounting, 30(3-4), 573-588. https://doi.org/10.1111/1468-5957.00008

Dewi, S. C. (2008). Pengaruh kepemilikan managerial dan kepemilikan institusional, kebijakan hutang, profitabilitas dan ukuran perusahaan, terhadap kebijakan dividen. Jurnal Bisnis Dan Akuntansi, 10(1), 47-58.

Dhole, S., Mishra, S., \& Pal, A. M. (2019). Efficient working capital management, financial constraints and firm value: A text-based analysis. Pacific Basin Finance Journal, 58, 101212.

https:// doi.org/10.1016/j.pacfin.2019.101212

Edi, N., \& Saad, N. M. (2010). Working capital management: The effect of market valuation and profitability in Malaysia. International Journal of Business and Management, 5(11), 140147. https://doi.org/10.5539/ijbm.v5n11p140

Fristiani, N. L., Pangastuti, D. A., \& Harmono, H. (2020). Intellectual Capital Dan Kinerja Keuangan Terhadap Nilai Perusahaan: Pada Industri Perbankan. AFRE (Accounting and Financial Review), 3(1), 35-42. https://doi.org/10.26905/afr.v3i1.4223

Gamayuni, R. R. (2015). The Effect Of Intangible Asset Financial Performance And Financial Policies On The Firm Value. International Journal of Scientific \& Technology Research, 4(1), 202-212.

Goddard, J., Tavakoli, M., \& Wilson, J. O. S. (2005). Determinants of profitability in European manufacturing and services: Evidence from a dynamic panel model. Applied Financial Economics, 15(18), 1269-1282. https://doi.org/10.1080/09603100500387139

Haryanto, S., Bachtiar, Y., \& Khotami, W. (2020). Efficiency and profitability of Islamic banks in Indonesia. Inovator Jurnal Manajemen, 9(1), 4148. https://doi.org/10.1166/asl.2017.9975

Haryanto, S., Rahadian, N., Mbapa, M. F. I., Rahayu, E. N., \& Febriyanti, K. V. (2018). Kebijakan Hutang, Ukuran Perusahaan dan Kinerja Keuangan Terhadap Nilai Perusahaan: Industri Perbankan di Indonesia. AFRE (Accounting and Financial Review), 1(2). https:// doi.org/10.26905/afr.v1i2.2279

Kartika, D. N. P. I., \& Abundanti, N. (2019). Pengaruh leverage dan ukuran perusahaan terhadap nilai perusahaan dengan profitabilitas sebagai variabel mediasi. EJurnal Manajemen Universitas Udayana, 8(5), 3028.

https://doi.org/10.24843/EJMUNUD.2019.v0 8.i05.p16

Koralun-Bereźnicka, J. (2014). On the relative importance of corporate working capital determinants: findings from the EU Countries. Contemporary Economics, 8(4), 415$433 . \quad$ https://doi.org/10.5709/ce.18979254.154

Martínez-Solano, P., \& García-Teruel, P. J. (2007). Effects of Working Capital Management on SME Profitability. International Journal of Managerial Finance, 3(2). https://doi.org/10.2139/ssrn.894865

Mathuva, D. M. (2009). The influence of working capital management components on corporate profitability: A survey on Kenyan listed firms. Research Journal of Business Management, 4(1), 1-11. https://doi.org/10.3923/rjbm.2010.1.11

Moeljadi, M. (2014). Factors affecting firm value: Theoretical study on public manufacturing firms in Indonesia. South East Asia Journal of Contemporary Business, Economics and Law, $5(2), 6-15$.

Munawir, S. (2004). Analisis laporan keuangan (4th ed.). Liberty.

Nastiti, P. K. Y., Atahau, A. D. R., \& Supramono, S. (2019). Working capital management and its influence on profitability and sustainable growth. Business: Theory and Practice, 20, 6168. https://doi.org/10.3846/btp.2019.06

Nguyen, A. H., Pham, H. T., \& Nguyen, H. T. (2020). Impact of working capital management on firm's profitability: Empirical 
evidence from Vietnam. Journal of Asian Finance, Economics and Business, 7(3), 115-125. https://doi.org/10.13106/jafeb.2020.vol7.no3. 115

Ogundipe, S. E., Idowu, A., \& Ogundipe, L. O. (2012). Working capital management, firms' performance and market valuation in Nigeria. International Journal of Social, Behavioral, Educational, Economic and Management Engineering, 6(1), 19-23.

Padachi, K., Howorth, C., \& Narasimhan, M. S. (2012). Working capital financing preferences: The case of Maurutian manufacturing small and medium-sized enterprises (SMEs). Asian Academy of Management Journal of Accounting and Finance, 8(1), 125-157.

Panigrahi, A. K. (2017). Working capital management efficiency of Indian cement industry. NMIMS Journal of Economics and Public Policy, 11(January), 8-28.

Pervan, M., Pervan, I., \& Ćurak, M. (2019). Determinants of firm profitability in the Croatian manufacturing industry: evidence from dynamic panel analysis. Economic Research-Ekonomska Istrazivanja , 32(1), 968981.

https://doi.org/10.1080/1331677X.2019.15835 87

Phuong, D. H., \& Jyh-Tay, S. (2010). The relationship between working capital management and profitability: A Vietnam case. International Research Journal of Finance and Economics, 49(September), 62-71.

Pratama, I. G. B. A., \& Wiksuana, I. G. B. (2016). Pengaruh ukuran perusahaan dan leverage terhadap nilai perusahaan dengan profitabilitas sebagai variabel mediasi. EJurnal Manajemen Universitas Udayana, 5(2), 1338-1367.

Quayyum, S. T. (2011). Relationship between working capital management and profitability in context of manufacturing industries in Bangladesh. International Journal of Business and Management, 7(1), 58-69. https://doi.org/10.5539/ijbm.v7n1p58

Raheman, A., Afza, T., Qayyum, A., \& Bodla, M. A. (2010). Working capital management and corporate performance of manufacturing sector in Pakistan. International Research Journal of Finance and Economics, 47(September), 151-163.

Raheman, A., \& Nasr, M. (2007). Working capital management and profitability: Case of Pakistani firms. International Review of Business
Research Papers, 3(March), 279-300.

Raningsih, N. K., \& Artini, L. G. S. (2018). Pengaruh profitabilitas terhadap nilai perusahaan dengan corporate social responsibility sebagai variabel moderasi. E-Jurnal Ekonomi Dan Bisnis Universitas Udayana, 6(2), 1997-2026. https://doi.org/10.24843/EEB.2018.v07.i08.p 03

Rizqia, D. A., Aisjah, S., \& Sumiati, S. (2013). Effect of managerial ownership, financial leverage, profitability, firm size, and investment opportunity on dividend policy and firm value. Research Journal of Finance and Accounting, 4(11), 120-130.

Seelanatha, L. (2011). Determinants of firms' performance: Some Chinese evidence. Investment Management and Financial Innovations, 8(3), 28-38.

Setiaji, H. (2019). Melambat sejak 2015, penjualan ritel agak membaik di 2018. CNBC Indonesia.

Setyanto, A. D., \& Permatasari, I. (2014). Manajemen modal kerja dan dampaknya terhadap nilai perusahaan dengan corporate governance sebagai variabel pemoderasi. AKRUAL: Jurnal Akuntansi, 6(1), 68-82. https://doi.org/10.26740/jaj.v6n1.p68-84

Sharma, A. K., \& Kumar, S. (2011). Effect of working capital management on firm profitability: Empirical evidence from India. Global Business Review, 12(1), 159-173. https://doi.org/10.1177/097215091001200110

Sri, A., Dewi, M., \& Wirajaya, A. (2013). Pengaruh Struktur Modal, Profitabilitas Dan Ukuran Perusahaan Pada Nilai Perusahaan. E-Jurnal Akuntansi, 4(2), 358-372.

Sudana, I. M. (2011). Manajemen keuangan perusahaan: Teori dan praktik (2nd ed.). Erlangga.

Sutrisno, S. (2020). Corporate Governance, Profitability, and Firm Value Study on the Indonesian Sharia Stock Index. Jurnal Ekonomi Dan Bisnis Islam (Journal of Islamic Economics and Business), 6(2), 292. https://doi.org/10.20473/jebis.v6i2.23231

Syarief, M. E., \& Wilujeng, I. P. (2009). Cash conversion cycle dan hubungannya dengan ukuran perusahaan, profitabilitas dan manajemen modal kerja. Jurnal Ekonomi Bisnis, 1, 61-69.

Taftazani, A. M., Irwanto, A. K., \& Cahyadi, E. R. (2015). Dampak Krisis Keuangan Global 2008 terhadap Volatilisas Return Saham Perbankan di BEI. Jurnal Aplikasi Manajemen, 13(14), 9-16.

Tran, H., Abbott, M., \& Yap, C. J. (2017). How does 
Apakah Profitabilitas Memediasi Pengaruh Manajemen Modal Kerja terhadap Nilai Perusahaan? Evan Yulandreano, Apriani Dorkas Rambu Atahau, dan Imanuel Madea Sakti

working capital management affect the profitability of Vietnamese small-and medium-sized enterprises? Journal of Small Business and Enterprise Development, 24(1), 211. https://doi.org/10.1108/JSBED-05-20160070

Wasiuzzaman, S. (2015). Working capital and firm value in an emerging market. International Journal of Managerial Finance, 11(1), 60-79. https://doi.org/10.1108/IJMF-01-2013-0016

Wibowo, M. A., \& Yuliana, I. (2020). Pengaruh Profitabilitas Terhadap Nilai Perusahaan Dengan Intellectual Capital Sebagai Vari-abel Moderasi. Inovator, 9(2), 75. https://doi.org/10.32832/inovator.v9i2.3424 